\title{
ADVANCING WOMEN'S RIGHTS IN DAVAO CITY, PHILIPPINES: \\ THE ROLE OF LOCAL CIVIL SOCIETY \\ Kelsey Coolidge | 2017
}

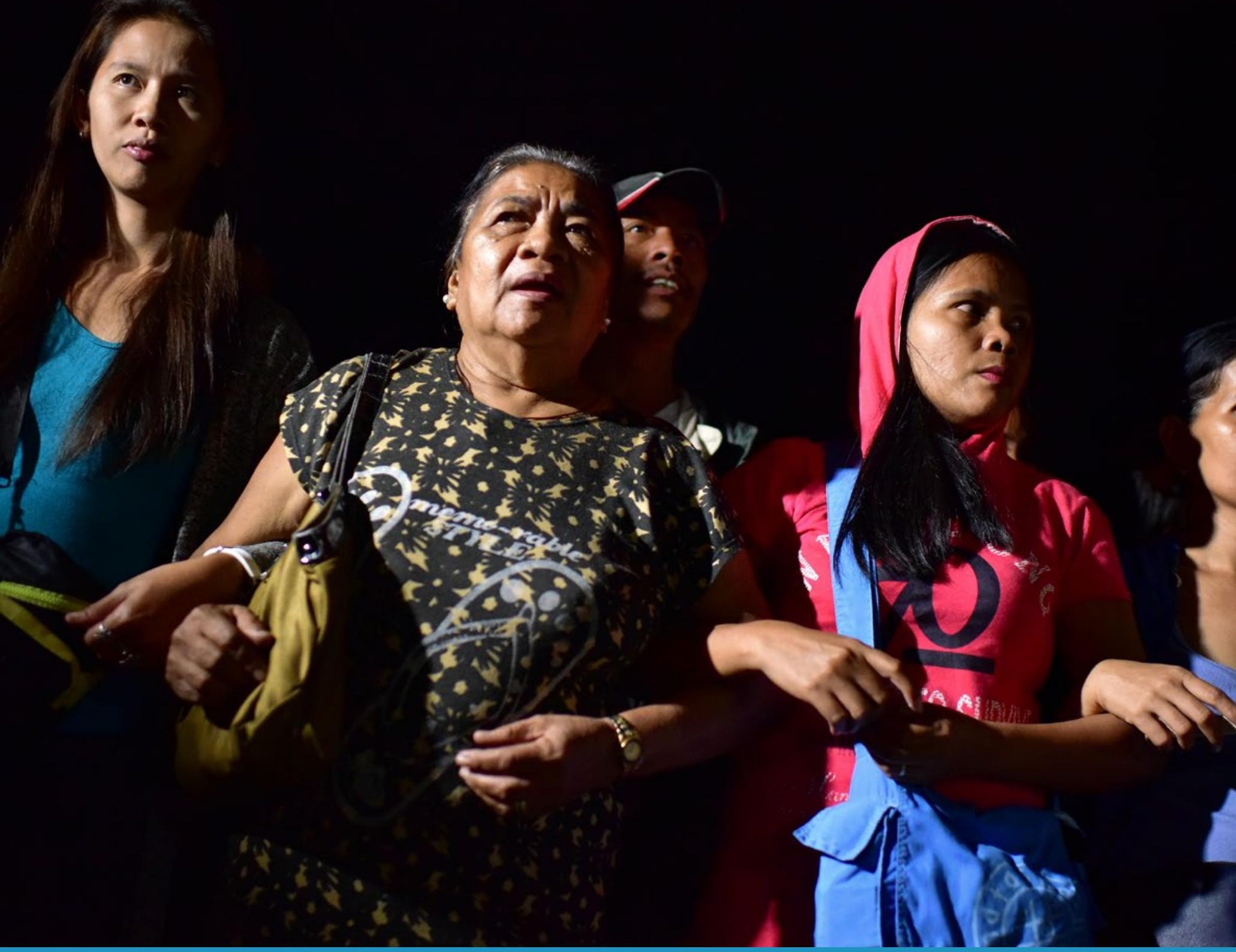

An OEF Research Discussion Paper

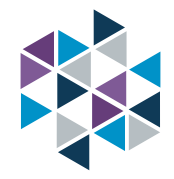

OEF Research 


\section{ADVANCING WOMEN'S RIGHTS IN DAVAO CITY, PHILIPPINES: THE ROLE OF LOCAL CIVIL SOCIETY}

Kelsey Coolidge | 2017

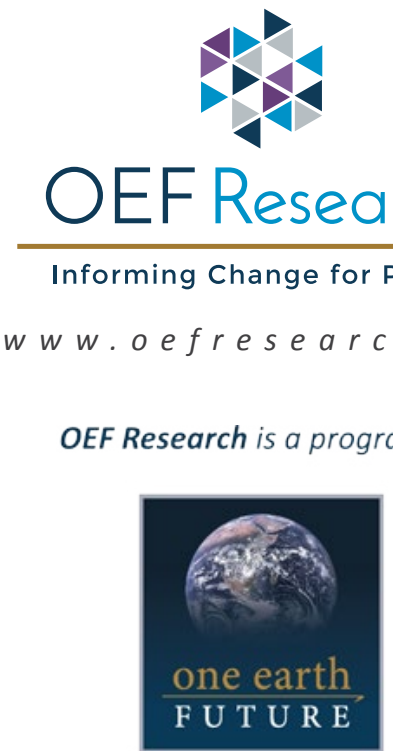

Peace Through Governance

oneearthfuture.org 


\section{ACKNOWLEDGMENTS}

Interview data included in this paper were collected in collaboration with Inclusive Security in a joint project on National Action Plans (NAPS) for implementing United Nations Security Council Resolutions 1325 and 1820. This project resulted in the report "From Global Promise to National Action: Advancing Women, Peace, and Security in the Democratic Republic of Congo, the Philippines, Serbia, and Sierra Leone," which reviews the implementation and impact of NAPs in those four countries. The report was released in October 2016 and is available online.

Design and layout by Andrea Kuenker, One Earth Future. 


\section{INTRODUCTION}

Civil society actors, institutions, and organizations distinct from the state and private businesses ${ }^{1}$ exert powerful influence on a state's implementation of international human rights law. ${ }^{2}$ However, previous research on this topic has overlooked how local civil society actors are able to implement international law on the local level. While previous research acknowledges the role that civil society actors play in supporting human rights, it generally focuses on activity at the national level. This paper argues that the influential role that civil society organizations (CSOs) play in supporting the implementation of international human rights also takes place at the local level, with grassroots organizations demanding changes from local governments on the basis of international law. This is supported by a case study on women's rights legislation in Davao City, Philippines, where local CSOs were the catalyst for the implementation of the Women and Development $\mathrm{Code}^{3}$, a wide-reaching piece of legislation affirming women's rights within the city. The Women and Development Code directly implemented the Convention on the Elimination of Discrimination Against Women (CEDAW), known as the "international bill of rights for women," outlining all forms of women's social, economic, and political rights. ${ }^{4}$ Remarkably, this code was passed and implemented in the city more than a decade before similar legislation was passed on the national level.

This paper provides evidence that local CSOs can leverage international law to demand changes at the local level and suggests that unique social and political characteristics in the Philippines supported local activism. The Philippines boasts a vibrant civil society with wide public support and participation, ${ }^{5}$ which research shows is the single most important factor determining a state's implementation of international human rights, especially women's rights. ${ }^{6}$ The Philippines' history of internal conflict and political instability also provides the basis for human rights activity on the local level. This paper will detail how local CSOs in Davao City were able to accomplish implementation in the context of emerging democratic rule and within a deeply divided society, and will provide supporting evidence from interviews recorded in September 2015.

\section{LITERATURE REVIEW}

Because the implementation of international human rights law is traditionally considered to be the purview of national governments, ${ }^{7}$ much of the literature focuses on its successes and failures at the state level. Empirical research has found that democratization and human rights ratification are related, ${ }^{8}$ but are "most effective in stable or consolidating democracies." ${ }^{\prime 9}$ This is in line with the Philippines' experience after the 1986 ousting of autocratic leader Ferdinand Marcos, which jumpstarted the flourishing of social, political, civil, and other human rights. However, there is a lack of consensus in the literature; others found that all states make human rights obligations as "window dressing"10 and that human rights treaties have no effect on the states considered to be the "most terrible repressors." ${ }^{11}$ Repressive states ratify human rights treaties as much as non-repressive states, calling into question what motivates states to sign human rights treaties in the first place..$^{12}$

Research has found that international human rights treaties have the greatest effect when local citizens demand compliance..$^{13}$ This suggests a missing factor in cross-national research on the implementation of human rights; namely how local demands affect the state's willingness to implement human rights law. Research examining the link between local demands for human rights and international pressure for compliance has promising results. For example, cross-national research shows that the partnership between international feminist organizations

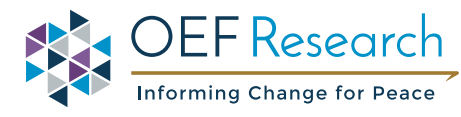




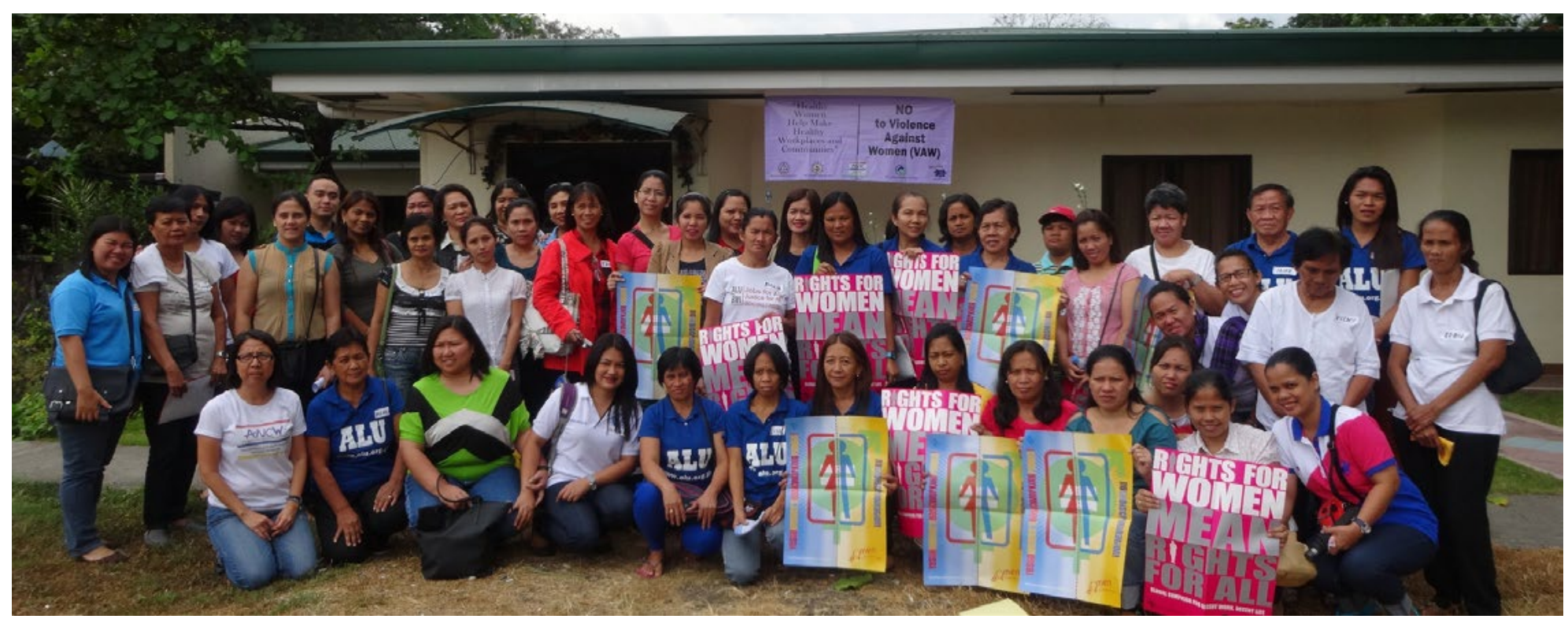

International Women's Day celebration. Photo: International Transport Workers Federation

and autonomous domestic women's organizations is the most significant factor accounting for changes in national laws on violence against women, more significant than the existence of leftist parties, the percentage of women in government, or GDP. ${ }^{14}$ This work is meaningful because it reinforces the idea that local organizations are at the center of progress on human rights in diverse contexts, and, specific to women's rights, have significant impacts by "[legitimatizing] women's demands at the domestic level for freedom from violence." ${ }^{15}$

CSOs are "integral to creating the political salience of human rights." ${ }^{16}$ The literature on this topic frequently employs the example of the involvement of CSOs in women's rights activity worldwide. ${ }^{17}$ Perhaps more than any other human rights issue, CSOs are fundamental to identification, expansion, and monitoring of women's rights. The book Activists Beyond Borders describes how transnational and local women's organizations have increased international attention toward violence against women, leading to specific policy changes at the state level, as one example of its argument on how transnational advocacy networks advance human rights globally. ${ }^{18}$ Other research focused on how "women's organizations succeeded in placing front and center on the UN agenda two issues that had been perceived as exclusively private: violence against women and reproductive health and rights, " as an example of civil society's ability to influence the international political agenda, and subsequently state behavior. ${ }^{19}$

The process by which CSOs influence policy change reveals how CSOs operate between national governments, the international community, and human rights. Research examining the role of CSOs in the policy-making process has resulted in a number of different theories and models. ${ }^{20}$ Of particular relevance to this case study, the "spiral model" underscores how CSOs coalesce around certain policy issues and organize advocacy campaigns. This social learning model emphasizes how governments, CSOs, and other international organizations are essential to solving social, economic, and environmental problems, or "problem domains." Within these domains, organizations play unique roles to "increase awareness, capacities, and repertoires of action amongst actors in a [problem] domain." ${ }^{21}$ The model outlines the roles that CSOs play, which include "identifying emerging issues, facilitating a grassroots voice,... amplifying the public visibility and importance of issues, and monitoring and problem-solving performance." ${ }^{22}$ Local organizations in Davao City played these roles to support the passage of the Davao City Women and Development Code, working directly with government and eventually playing formal roles in government bodies overseeing its implementation.

In short, the existing literature shows that all states sign human rights treaties regardless of their human rights records. The work of local civil society is essential to ensuring compliance with the treaties that states sign. Activism 
around women's rights demonstrates this point, as women's organizations worldwide have been fundamental to identifying women's rights and placing those issues on the international human rights agenda. Because CSOs are deeply involved in human rights, there is a rich literature that explores what specific roles they play in affecting state behavior on human rights. However, this literature focuses on activity at the state level, and little existing research considers how this may operate at local levels within the state. The following case study delves into the gap, suggesting potential new ways to examine local CSOs and the implementation of international human rights law.

\section{WHAT IS THE SIGNIFICANCE OF THE WOMEN AND DEVELOPMENT CODE?}

While previous research has documented the role CSOs play in human rights implementation at the national level, this paper argues that local CSOs directly apply international human rights law to support and advance their social and political campaigns targeting local policy. The case of the Women and Development Code in Davao City offers a unique contribution by identifying local-level activity to implement women's rights based on CEDAW that preceded activity on the national level. Furthermore, it constitutes a new approach which emphasizes the formal role that CSOs can play in the governance of human rights. In the Philippines, local CSOs capitalized on a moment in Philippine history that was most receptive to CSO involvement; a time following the People Power movement and during major changes to the political and social climate in Davao City under the leadership of then-mayor Rodrigo Duterte.

To describe it borrowing language from the spiral model, local CSOs identified the emerging issue of women's rights and CEDAW as the model for a desirable set of local laws aimed at improving the status of women in Davao City. These local CSOs operated on the grassroots level and represented the concerns of local women while generating public support for women's rights. Because the code designated formal mechanisms for the inclusion of women's organizations in local governing structures, these local organizations played a direct role in monitoring the implementation of the code by identifying specific relevant policies and programs while serving in appointed government positions and attending annual strategic meetings.

The Davao City example suggests that there can be multiple pathways for implementation of international law, including pathways where action on the local level precedes national action.
This process has important implications for the implementation of international human rights, and particularly for women's rights. First, it suggests that international law can be implemented on the local level without legislation on the national level. The typical approach to international law implementation assumes that states implement international law nationally prior to activity at the local level. ${ }^{23}$ The Davao City example suggests that there can be multiple pathways for

the implementation of international law, including pathways where action on the local level precedes national action. This is significant because it expands the number of relevant actors in human rights discourse and opens future research to examining activity on the sub-state level.

Second, this example reveals social and political factors that may facilitate local CSO activity on implementation of international human rights. In deeply divided societies like the Philippines, where "violence or the threat of violence keeps it divided" 24 and distrust falls along a center-periphery divide, ${ }^{25}$ the ability of the national government to effectively govern human rights is compromised by a number of social and political realities. Interviews with local organizations provided evidence of this, with some expressing distrust or ambivalence when asked about their relationship with the national government. As a result, organizations, especially if located in conflict-affected areas, are less prone to demand changes from the national government and instead opt to demand changes from the

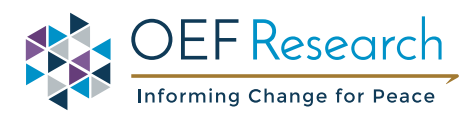


local government. This works when there is evidence of a strong, vibrant, and independent civil society, much like the one reported in the Philippines. Finally, the emerging democratic rule following the end of the Marcos regime jumpstarted citizens' demands for a stronger adherence to international human rights treaties, which is consistent with the literature that shows that human rights laws are more effective in emerging democracies. ${ }^{26}$

This paper does, however, lack information detailing the linkages between international actors and local actors in Davao City and the link from Davao City to the national government, which constitute a significant gap. Existing literature on this topic links engagement between international and local actors as being a significant factor for human rights implementation. ${ }^{27}$ Some interviewees referred to international funding being provided for women's organizations in Davao City during this time, but that funding is unverified and the recipients of those funds were not explicitly named in the interviews. ${ }^{28}$ Additionally, comprehensive legislation on women's rights was passed in the Philippines on the national level in 2010, a decade after the Women and Development Code in Davao City. There is likely a connection between the passing of the Women and Development Code in Davao City in 1997 and the Magna Carta of Women ${ }^{29}$ nationally in 2010. However, no evidence collected in interviews or through secondary research has confirmed or denied a link. These gaps justify further research on this case study. Nonetheless, this paper offers a unique contribution to the field by presenting a case where local implementation of international women's rights preceded activity on the national level.

\section{METHODOLOGY}

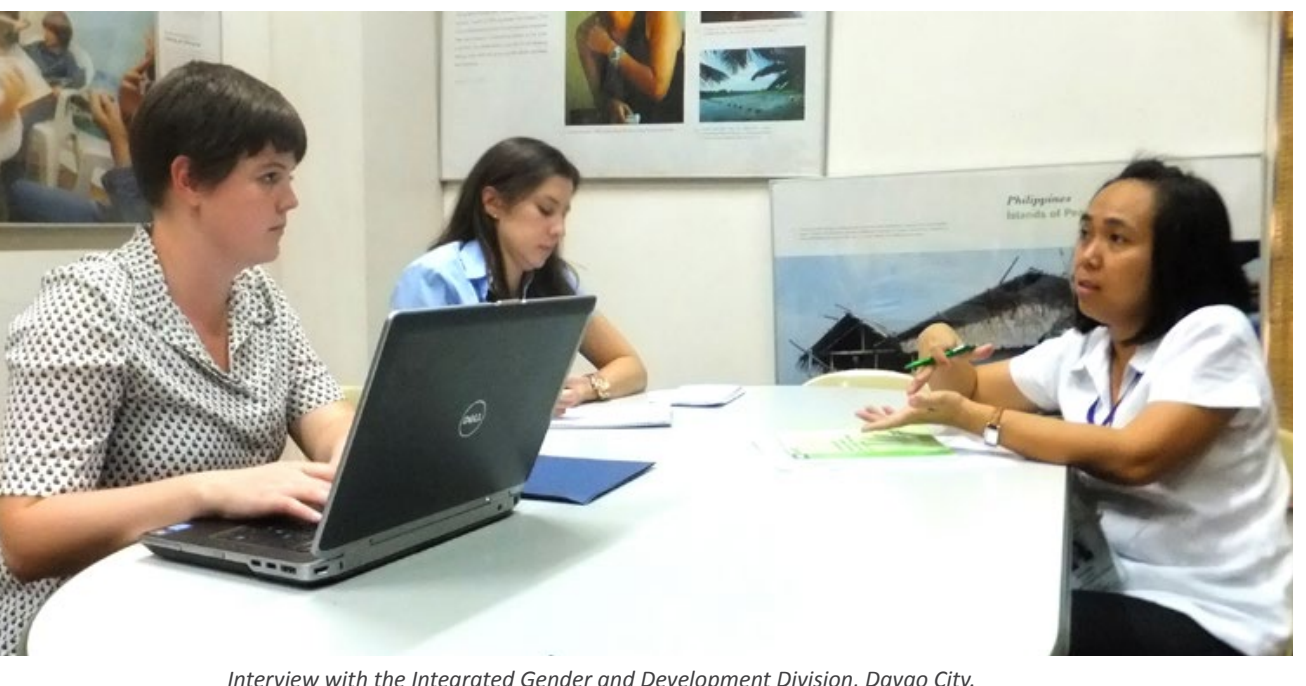

The interviews referenced were conducted for a collaborative research project ${ }^{30}$ on National Actions Plans (NAPs) for the implementation of United Nations Resolution 1325. For this research, approximately 20 representatives from government, the security sector, and civil society were interviewed on their perceptions of 1325, NAPs, and the relationship between civil society and government. These interviews

took place in Manila and Davao City in September 2015. While the interviews were not specific to the scope of this research paper, participants provided information relevant to the case study. Additional desk research was conducted from 2015-2016 with analysis of key pieces of legislation on women's rights in the Philippines.

\section{POLITICS, VIOLENCE, AND STRENGTHENING CSOs IN THE PHILIPPINES}

It is valuable to cover the development of women's rights throughout the 1990s and early 2000s in Davao City, the capital of the southernmost Philippine island of Mindanao. The proliferation of women's formal political and social rights in the Philippines began with the end of the Marcos regime in 1986. It is important to characterize the political and social context at the time of his removal from power; the Marcos regime neglected human rights, but that 


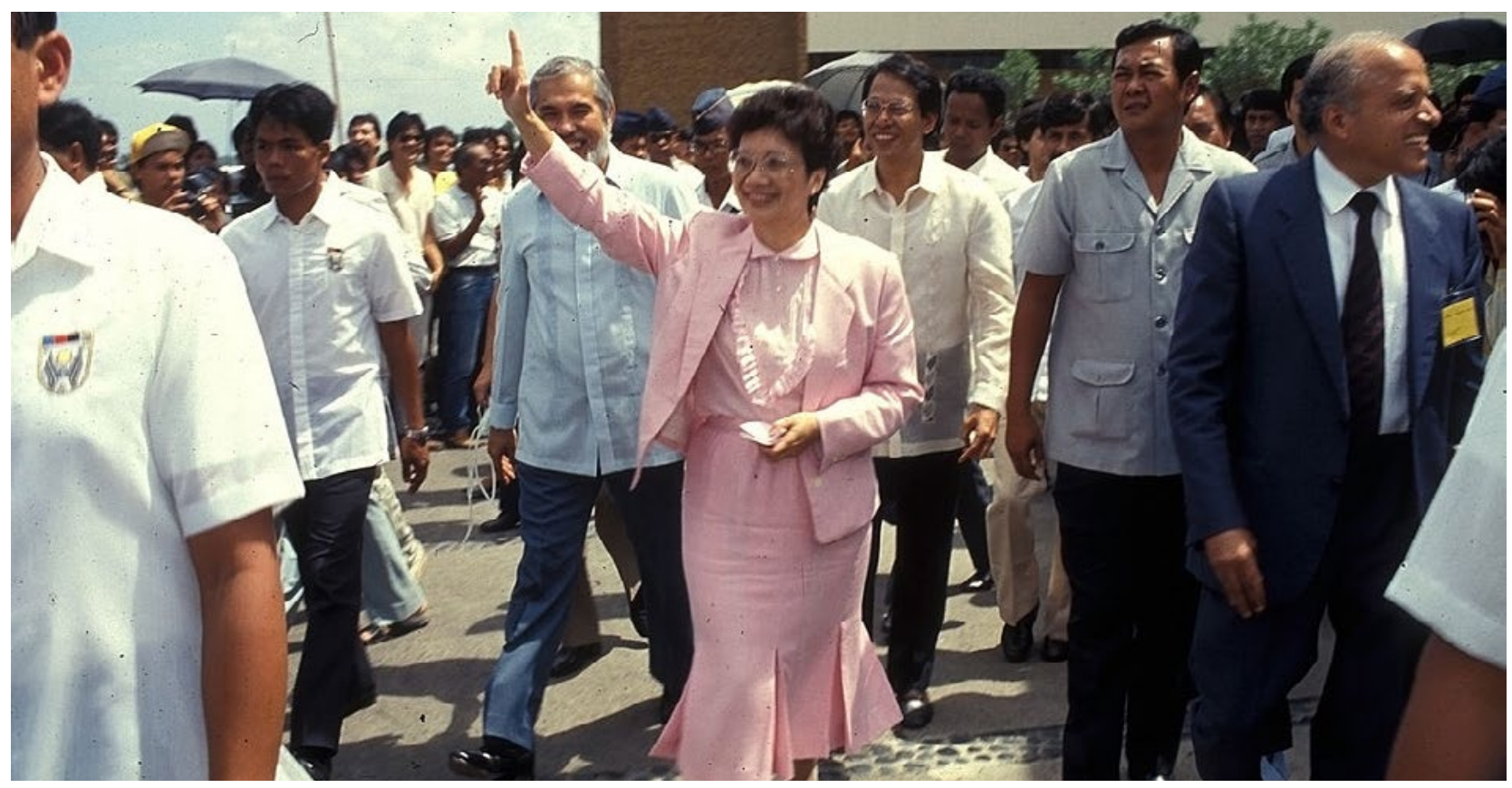

President Corazon Aquino in 1986. Photo: IRRI Images

changed following the election of Corazon Aquino, the first democratically elected (and first female) president, in 1986. This political upheaval, combined with stronger engagement with international human rights, contributed to the country's transformation.

The popular People Power movement is credited with removing Marcos from power. This revolution was a pivotal moment for CSOs in the Philippines. ${ }^{31}$ Led by Aquino, it coalesced diverse CSOs including the Catholic Church, women's organizations, indigenous groups, and others, ${ }^{32}$ and helped to create a surge of public support for CSOs. Even today, data from the Civil Society Index assessment of the Philippines shows that an estimated $75 \%$ of the Philippine population participates in CSOs and $50 \%$ consider themselves actively involved. ${ }^{33}$ The OEF Research and Inclusive Security interview data confirm the perception of a vibrant and active civil society in the Philippines. ${ }^{34}$

Understanding this context is important for examining CSOs' activity on women's rights in Davao City. The Marcos regime engaged in direct violence against many members of the indigenous and Muslim populations living in Mindanao. The move to martial law in 1965, which lasted until Marcos' ousting in 1986, was motivated by the rebellion of the Moro National Liberation Front (MNLF) in Mindanao and the ongoing leftist-communist rebellion throughout the country. ${ }^{35}$, 36 In particular, the Moro rebellion was motivated by decades of perceived neglect and unequal treatment by the national government targeting Muslim populations in Mindanao. ${ }^{37}$ Davao City was often at the epicenter of violence between the Armed Forces of the Philippines, the National Police, Moro rebels, and leftist groups. Still today, Mindanao is relatively underdeveloped in comparison to other regions in the Philippines and is host to occasional violence despite the formal ending of hostilities with Moro rebels in 2014. ${ }^{38}$

This context contributed to a reported lingering mistrust and ambivalence toward the national government. ${ }^{39}$ Some interview questions gauged the relationship between CSOs and various levels of government, and whether specific pieces of legislation at the national level had any effect on those relationships. Responses indicated that many local CSOs believed that policies created at the national level failed to represent the voices and interests of those at the local level. When asked about their relationship with the national government, many

\section{Responses indicated that many local CSOs believed that policies created at the national level failed to represent the voices and interests of those at the local level.}




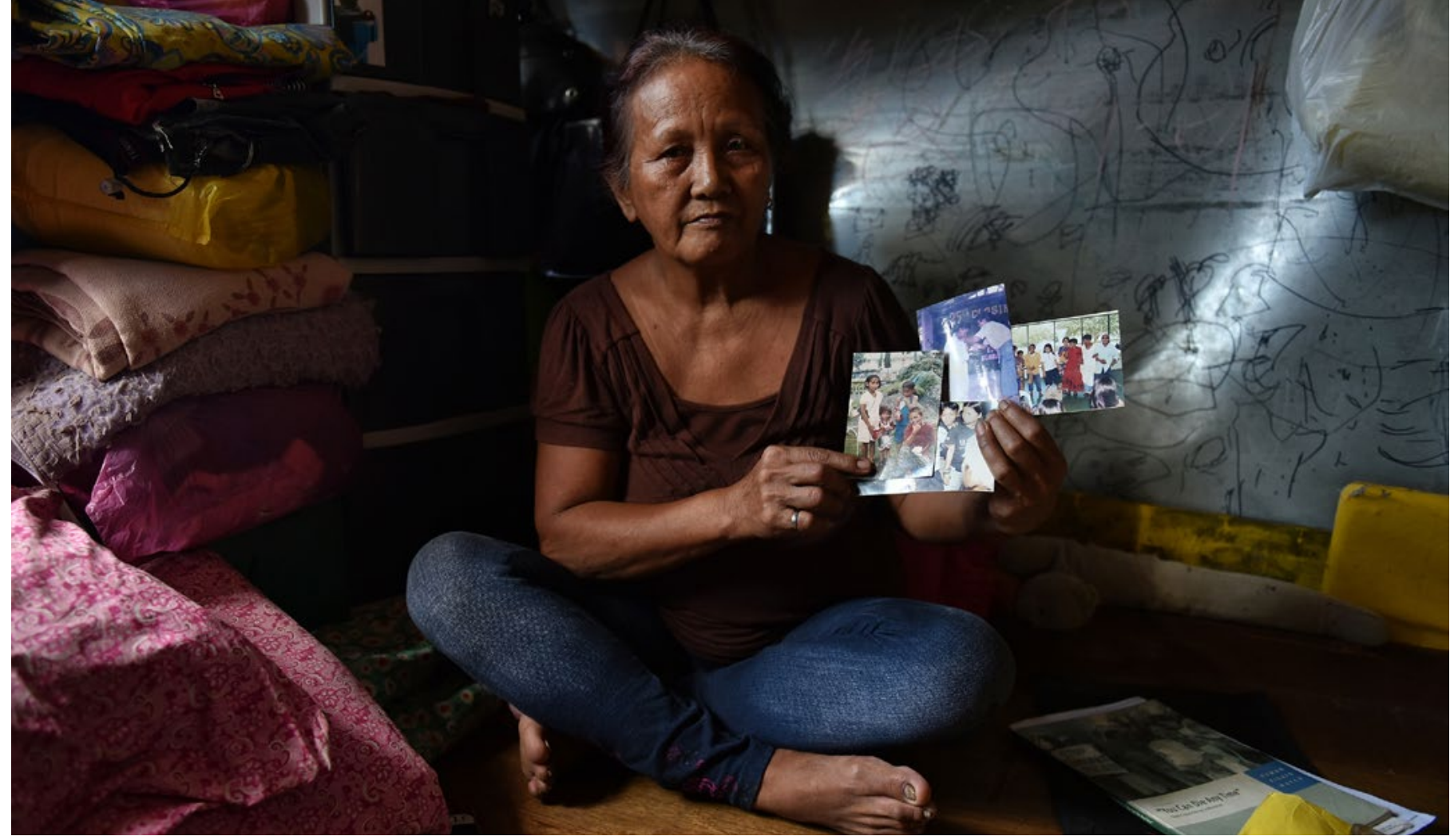

Clarita Alia shows photos of her four sons allegedly killed by the Davao Death Squad. Photo: Jes Aznar/Getty Images

local CSOs responded with general indifference and suggestions that the national government should interact more directly with communities in Mindanao. ${ }^{40}$ In contrast, reported interactions with local government were more positive, with one interviewee suggesting that "action should be at the local government level." ${ }^{41}$ In this context, local government benefitted from directly connecting and engaging with communities on a grassroots level, further supporting CSOs as being a legitimate venue for political representation in the city.

Furthermore, the end of the Marcos regime nationally was shortly followed by Rodrigo Duterte's first term as mayor of Davao City in 1988. Now president of the Philippines, Duterte held three separate terms, two consecutive and one non-consecutive, as mayor of Davao City before winning the presidential election in 2016. His tenure marked a departure from those of previous mayors in the city; namely, he asserted far greater control over city affairs.

Many in Davao City credit Duterte with taking a strong and heavy-handed stand against crime and lawlessness and contributing to the wide perception that the city was becoming safer and more economically prosperous. ${ }^{42}$ The New York Times reported in early 2017 that Duterte built "a clean and efficient city by Philippine standards," and noted that by the time he left for the presidency in 2016, "the city had drinkable tap water and approved business permits within 72 hours." ${ }^{43}$ Yet, in 2002, Time magazine coined Duterte "The Punisher" for his ruthless tactics. ${ }^{44}$ The article describes the peace and stability achieved under Duterte as coming "at a grim price," and charged Duterte with "disregarding due process and anointing himself legislator, judge, jury-and possibly executioner-all at once." 45 Stories of the Davao Death Squad (DDS) - also known locally as the "Duterte Death Squad" - abound, alleging that members targeted suspected criminals involved in crimes ranging from petty theft to drug smuggling and selling. ${ }^{46}$

Paired with an emboldened civil society following the end of the Marcos regime and the newly strengthened political control assumed by Duterte in Davao City, local CSOs capitalized on an opportunity to advocate for improved laws and policies on women's rights based on CEDAW. On the national level, the Philippines signed CEDAW in 1980 but was unable to pass national legislation on women's rights until the early 1990s. This includes the Women in Development and Nation Building Act in 1993 (RA 7192), ${ }^{47}$ the Anti-Rape Law of 1997 (RA 8353), ${ }^{48}$ and the AntiViolence Against Women and Their Children Act of 2004 (RA 9262). ${ }^{49}$ All of these were later subsumed under the Magna Carta of Women, a wide-reaching legislative framework passed in 2010. Nearly all participants interviewed in 2015 talked at length about the Magna Carta, focusing on its successes and obstacles to implementation. ${ }^{50}$ Notably, 
the Magna Carta demands that all government bodies devote $5 \%$ of their budgets to gender and development programs, activities, and policies.

While the women's rights legislation at the national level is impressive, as one interview participant noted, saying "In Asia, the Philippines is a champion of legislation...We have beautiful laws, comparable to first-world countries," 1 an equally comprehensive Women and Development Code was passed in 1997 and fully implemented by 2003 in Davao City, a decade before the Magna Carta on the national level. It took the Philippines 30 years to pass the 2010 Magna Carta for Women after signing CEDAW in 1980, while Davao City accomplished it in 17 years (1997). This case demonstrates the influential role of local CSOs in developing and implementing policy at the local level. As one organization reported in 2015, "We are proud of our Women and Development Code."52

\section{LOCAL CSOs AND DAVAO CITY'S WOMEN AND DEVELOPMENT CODE}

Beginning in approximately 1995, local CSOs initiated the campaign to create and pass the Women and Development Code. ${ }^{53}$ When asked what influenced their work, local CSOs directly referenced CEDAW, saying, "We use it heavily. We invoke it." 54 Some organizations provided research outlining the needs of women in Davao. For example, Ateneo de Davao University's Social Research and Training Development Office conducted a research project on "Reproductive Health, Gender, and Sexuality" from 1994 to 2010, focusing on the "nexus of reproductive health, conflict, and gender." 55 Others generated public support for the Women and Development Code through public education campaigns that included puppetry and drama presentations. ${ }^{56}$

Particularly important is the code's formal inclusion of local CSOs in governance institutions in the city, formalizing these organization's monitoring and problem-solving capacity.
The Women and Development Code passed in October 1997 under Mayor Duterte, and explicitly referenced CEDAW, borrowing the definition of women's rights as "the rights of women that are defined and declared by the United Nations under the Convention on the Elimination of Discrimination Against Women (CEDAW) which we hereby adopt." 57 The code is colloquially referred to as a "baby CEDAW"58 and includes comprehensive provisions on political

participation, employment, health, education, cultural identity, gender and development, and women's support systems. It required $30 \%$ of official development assistance funds ${ }^{59}$ to "support programs and activities for women." 60 City officials interviewed in 2015 identified CEDAW as significantly affecting their work. Particularly important is the code's formal inclusion of local CSOs in governance institutions in the city, formalizing these organizations' monitoring and problem-solving capacity.

The code mandates the city government to actively consult with CSOs and requires nongovernmental organization representation in government bodies. Article II of the code, on the "Political and Public Sphere of Women," outlines specific government bodies that are mandated to reserve seats for women. This section calls for a special Council for Women, organized at the district level in Davao, that would formally include women in local governing structures. Section 31 of Article II calls for "women sectorial representatives to the Sangguniang Panlungsod ${ }^{61}$ [who] shall be elected by members of the accredited women's organizations in Davao City as a concrete manifestation of women's places in local governance," ${ }^{62}$ while Section 32 calls for the representation of women in the Barangay Development Councils. ${ }^{63}$ 
In the years following its implementation, the activities organized around the code resulted in some successes. The University Research Council at Ateneo de Davao reported involvement in gender sensitivity training with local police throughout the 1990s and 2000s, and noted that this was a "civilian initiative." ${ }^{64}$ In 1998, Davao City opened its first "Child-Minding Center" for children of government employees. This center directly fulfilled a mandate from the code to provide "basic services and facilities" for families, and signaled the government's commitment to the code. ${ }^{65}$ However, despite these successes, the code was not fully operationalized until 2003. When the code was first passed in 1997, it included a requirement that the related interim body scale its size to 99 employees before it could be considered an officially sanctioned government office. While this interim body existed after 1997, it was unable to scale up and, as result, no government office was mandated to oversee, monitor, and ensure its full implementation and compliance; it was local CSOs who were at the center of the campaign to fully implement the code.

A team composed of both local CSOs and government officials suggested amendments to the Women and Development Code to override that requirement and to fully commit Davao City to implementation of the code. Executive Order No. 24 passed in 2003 and created the Integrated Gender and Development Division (IGDD), which is housed in the Office of the Mayor. This division is mandated to execute the provisions of the Women and Development Code and is reportedly the only permanent Women and Development office on the city level in the Philippines. ${ }^{66}$

The IGDD attributes their achievements to the strong women's movement in the city. ${ }^{67}$ The division maintains its relationship with local CSOs through a variety of policies and programs including the annual Women's Summit, which was mentioned in many interviews. Every year, the division runs this event with local groups to discuss issues affecting women in Davao City, and aims to prioritize policies and programs for the city to implement. For example, emerging from the 2004 Women's Summit, CSOs identified the need for better access to legal counsel for women, particularly for female victims of domestic violence. ${ }^{68}$ As result, the city created the Office of the Special Counsel on Violence Against Women and Children, which provides pro-bono legal services for female victims of domestic violence.

One of the many reported successes of the IGDD is increasing the number of women in government positions. Beginning in 2010, the IGDD provided workshops on political campaigning in order to prepare female candidates to run for office. The division reported in 2016 that for the first time in city history, $40 \%$ of the Davao City Council was female for the 2013-2016 term. However, participation levels at lower echelons of government in the city remain as low as $16 \%$, which highlights the continued need for training and support systems for potential female candidates at the grassroots level..$^{69}$ The interviewed IGDD representative also detailed the division's work in providing a safe and enabling environment in prisons for female inmates, noting that it is recognized as having

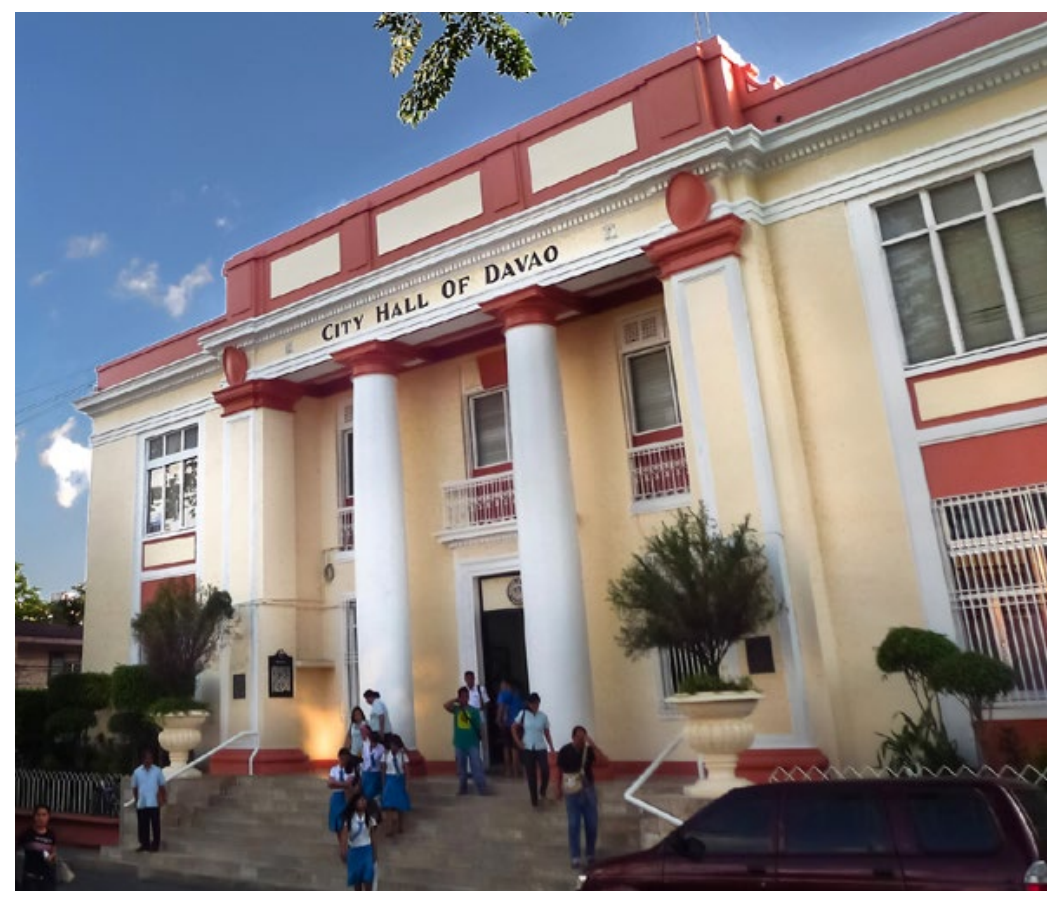

Davao City Hall. Photo: Jeffrey Pioquinto SJ 
"the first detention facility of the Philippines penology management [bureau] catering exclusively to the well-being of female inmates." 70

As a result of this body of work, the division reported that many local and national government bodies in the Philippines come to Davao City to learn about gender. The city was formally designated by the Philippine Commission on Women as a "Local Learning Hub on gender training." The IGDD was also awarded the Galing Pook ${ }^{71}$ award in 2005 for their work on gender responsiveness. ${ }^{72}$

Using CEDAW to inform their understanding of women's rights, local CSOs capitalized on the political moment to advance women's rights through local legislation in Davao City. Playing many of the same roles outlined in the spiral model, local CSOs generated local support for women's rights and collaborated with the government to pass the Women and Development Code. Formal inclusion in governing structures allowed local CSOs to ensure the code's implementation, and they followed up to support the code's effective enforcement through the creation of the IGDD. This case not only supports existing literature outlining the influential role CSOs play in supporting human rights, but also provides new ways to study human rights. This case emphasizes an expansion in the number of actors relevant to the implementation of human rights and suggests that more work should be done analyzing human rights at the sub-state level.

\section{DISCUSSION}

Local CSOs in Davao City invoked CEDAW to support their social and political campaigns to improve the status of women. They successfully did so by working with the local government in Davao City, becoming formally included in the policy-making process. This case has important implications for understanding how international human rights law is implemented within states and the ways in which local CSOs are at the forefront of change. There are exceptional aspects of this case that should be explored further. As stated, the Women and Development Code was implemented in Davao City more than a decade before similar national-level legislation was passed. This shows that local CSOs can demand changes on the local level and produce truly innovative results without support from the national government.

This finding questions the orthodoxy by which states sign and implement international human rights treaties. As evidenced by the language of most international treaties, the state is viewed as the sole provider and protector of human rights and any activity around human rights implementation should necessarily involve the state. Despite this, many states have a mixed record on human rights, even when they sign international human rights treaties. ${ }^{73}$ While the Philippines was a signatory to CEDAW when the Women and Development Code in Davao City passed, it had failed to otherwise implement the treaty through national legislation. Because of local CSOs, Davao City was the first to implement legislation on women's rights based on CEDAW. This demonstrates the possibility that international law can be applied locally without national-level compliance, further proving the central and powerful role that CSOs play in advancing human rights.

Beyond the central role of $\mathrm{CSO}$, there are other social and political factors about this case that enabled CSO activity on the local level. After the removal of the Marcos regime, local CSOs were empowered by the success of the People Power movement to take an active role in shaping government. The movement proved that it was possible for them to do so. In addition to using international law to support their social and political campaigns, local CSOs operated in a

local context which favored local action. In Davao City, the history of tenuous relations with the national government
In addition to using international law to support their social and political campaigns, local CSOs operated in a local context which favored local action.

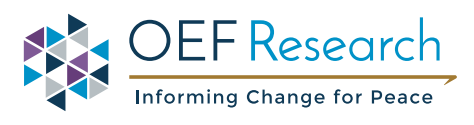


supported local activism in the face of perceived neglect or indifference to the national political discourse. Duterte's time as mayor also presented an opportunity for these organizations to gain support and push through legislation. These organizations could rely on Duterte to pass, implement, and enforce the laws, among the other initiatives that he supported with a heavy hand.

This suggests an interesting paradox between emerging democratic rule on the national level, which served to embolden local CSOs in the first place, and the emergence of a more powerful, perhaps more autocratic, leader in Davao City who served to push through their demands. This case highlights important questions about what type of governing institution is best suited to supporting and implementing human rights. While most literature will point to the link between better adherence to human rights treaties and emerging democracies, ${ }^{74}$ this case suggests that some rights, like women's rights, may gain support under autocratic rule, while others, like civil and political rights of due process, may suffer. To be clear, Duterte is no dictator. He was (and is) an elected official who continues to amass popular support. But the extent of the power he assumed as "The Punisher"75 is undeniable.

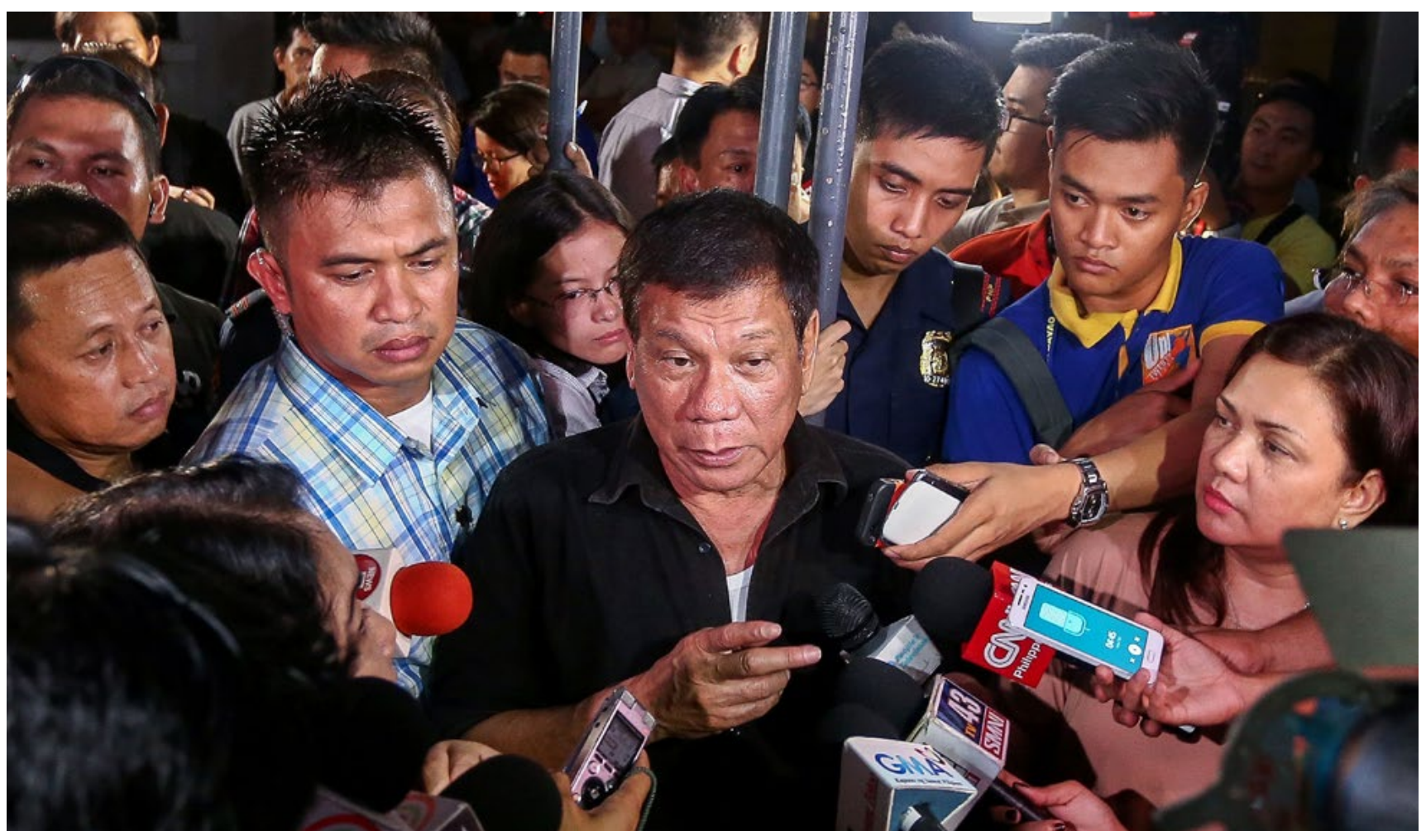

Rodrigo Duterte speaks to journalists in Davao City. Photo: Manman DeJeto/AFP/Getty Images

Furthermore, the example of Davao City demonstrates how local CSOs can continue to support the implementation of international human rights in deeply divided societies that consistently face the threat of violence. The lack of trust between many in Mindanao and the national government resulting from decades of government-sponsored violence did not deter local CSOs from supporting human rights. Instead, this prevailing political and social context supported action on the local level. Threats of violence did not deter these organizations from pursuing stronger legislation on women's rights. As one organization stated, "Democratic space matters. We have proven ourselves to engage [with the government and others] despite martial law. What more now?"76 While the Philippines continues to experience violence, either through state-sponsored killings of suspected drug users and dealers ${ }^{77}$ or terrorism conducted by a number of armed groups in the country, ${ }^{78}$ the fact that local CSOs can continue to support human rights demonstrates the incredible influence and resilience of the civil society at large.

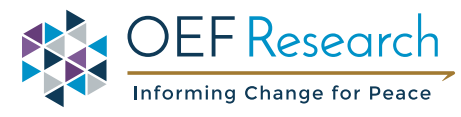




\section{CONCLUSION}

These factors suggest that local-level activity on human rights is not limited to Davao City. Areas with a strong and vibrant civil society, located within deeply divided societies, with a local government exerting a strengthened capacity to enforce law and order, and within the broader national context of burgeoning democratic rule may also experience a flourishing of human rights at the local level. Some initial examples include women, peace and security advocacy across the world; for example, in Palestine where women's organizations have successfully pushed for the Palestine Liberation Organization to pass a National Action Plan on United Nations Security Council Resolution $1325 .^{79}$ There is an opportunity to develop new and innovative research on this subject that can reframe the types of questions commonly asked about human rights, including their implementation and what roles governments and civil society play.

\section{REFERENCES}

1 Caucus of Development NGO Networks, "Civil Society Index: A Philippine Assessment Report," Assessment Report (Quezon City, Philippines: August 2011).

2 Margaret E. Keck and Kathryn Sikkink, Activists Beyond Borders: Advocacy Networks in International Politics (Ithaca, NY: Cornell University Press, 1998); Wendy H. Wong, Internal Affairs: How the Structure of NGOs Transforms Human Rights (Ithaca, NY: Cornell University Press, 2012); Lesley Wexler, "The International Deployment of Shame, Second-Best Responses, and Norm Entrepreneurship: The Campaign to Ban Landmines and the Landmine Ban Treaty," SSRN Scholarly Paper (Rochester, NY: Social Science Research Network, 2003), http://papers.ssrn.com/abstract=2171393; Thomas Risse, Stephen C. Ropp, and Kathryn Sikkink, The Power of Human Rights: International Norms and Domestic Change, Cambridge Studies in International Relations, 1999, http://www.cambridge.org/us/academic/subjects/politics-international-relations/international-relations-and-international-organisations/power-human-rights-international-norms-and-domestic-change; Sanjeev Khagram, James V. Riker, and Kathryn Sikkink, eds., Restructuring World Politics: Transnational Social Movements, Networks, and Norms, NED-New edition, vol. 14 (University of Minnesota Press, 2002), http://www.jstor.org/stable/10.5749/j.ctttsc5q; Michael Edwards and John Gaventa, eds., Global Citizen Action (Boulder, CO: Lynne Rienner Publishing, 2001); Ann M. Florini, ed., The Third Force: The Rise of Transnational Civil Society (Tokyo: Carnegie Endowment for Int'l Peace, 2000); John Clark, ed., Globalizing Civic Engagement: Civil Society and Transnational Action (London: Routledge, 2003); L. David Brown and Vanessa Timmer, "Civil Society Actors as Catalysts for Transnational Social Learning," Voluntas: International Journal of Voluntary and Nonprofit Organizations 17, no. 1 (2006): 1-16; Jeffrey T. Checkel, "Why Comply? Social Learning and European Identity Change," International Organization 55, no. 3 (Summer 2001): 553.

3 "City Ordinance No. 5004 and Executive Order No. 24" (Office of the Mayor, Davao City, October 1997), http://www.usep.edu. $\mathrm{ph} / \mathrm{gad} / \mathrm{wp}$-content/uploads/sites/7/2015/09/city ordinance no 5004.pdf

4 United Nations General Assembly, "Convention on the Elimination of All Forms of Discrimination Against Women," December 18, 1979, A/RES/34/180, available at http://www.un.org/womenwatch/daw/cedaw/.

5 Caucus of Development NGO Networks, "Civil Society Index: A Philippine Assessment Report."

6 Mala Htun and S. Laurel Weldon, "The Civic Origins of Progressive Policy Change: Combating Violence Against Women in Global Perspective, 1975-2005," American Political Science Review 106, no. 03 (August 2012): 548-569, doi:10.1017/ S0003055412000226.

7 United Nations, Treaty Handbook, prepared by the Treaty Section of the Office of Legal Affairs, 2012, https://treaties.un.org/ doc/source/publications/THB/English.pdf.

8 Min Zhou, "Signaling Commitments, Making Concessions: Democratization and State Ratification of International Human Rights Treaties, 1966-2006," Rationality and Society 26, no. 4 (November 1, 2014): 475-508, doi:10.1177/1043463114546313.

9 Emilie M. Hafner-Burton and Kiyoteru Tsutsui, "Justice Lost! The Failure of International Human Rights Law to Matter Where Needed Most," Journal of Peace Research 44, no. 4 (July 1, 2007): 407-25, doi:10.1177/0022343307078942.

10 Emilie M. Hafner-Burton and Kiyoteru Tsutsui, "Human Rights in a Globalizing World: The Paradox of Empty Promises," American Journal of Sociology 110, no. 5 (March 2005): 1373-1411.

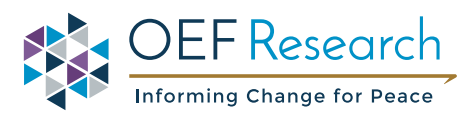


11 Hafner-Burton and Tsutsui, "Justice Lost! The Failure of International Human Rights Law to Matter Where Needed Most."

12 James Raymond Vreeland, "Political Institutions and Human Rights: Why Dictatorships Enter into the United Nations Convention Against Torture," International Organization 62, no. 1 (Winter 2008): 65-101; Emilie M. Hafner-Burton, Kiyoteru Tsutsui, and John W. Meyer, "International Human Rights Law and the Politics of Legitimation: Repressive States and Human Rights Treaties," International Sociology 23, no. 1 (January 1, 2008): 115-41, doi:10.1177/0268580907084388.

13 Beth A. Simmons, "Civil Rights in International Law: Compliance with Aspects of the 'International Bill of Rights,"' SSRN Scholarly Paper (Rochester, NY: Social Science Research Network, July 1, 2009), https://papers.ssrn.com/abstract=1517848.

14 Htun and Weldon, "The Civic Origins of Progressive Policy Change."

15 Jutta Joachim, "Framing Issues and Seizing Opportunities: The UN, NGOs, and Women's Rights," International Studies Quarterly 47, no. 2 (June 2003): 248, doi:10.1111/1468-2478.4702005.

16 Wong, Internal Affairs, 3.

17 R. Charli Carpenter, "Women and Children First': Gender, Norms, and Humanitarian Evacuation in the Balkans 1991-95," International Organization 57, no. 4 (Fall 2003): 661-94; Keck and Sikkink, Activists Beyond Borders; Htun and Weldon, "The Civic Origins of Progressive Policy Change."

18 Keck and Sikkink, Activists Beyond Borders, 165-98.

19 Joachim, "Framing Issues and Seizing Opportunities."

20 Keck and Sikkink, Activists Beyond Borders; Wong, Internal Affairs; Brown and Timmer, "Civil Society Actors as Catalysts for Transnational Social Learning."

21 Brown and Timmer, "Civil Society Actors as Catalysts for Transnational Social Learning," 3.

22 Ibid., 6.

23 "International Human Rights Law," United Nations Human Rights Office of the High Commissioner, accessed April 29, 2017, http://www.ohchr.org/EN/Professionallnterest/Pages/InternationalLaw.aspx.

24 Adrian Guelke,, "Book Review: Politics in Deeply Divided Societies," London School of Economics and Political Science Review of Books, November 17, 2012, http://blogs.Ise.ac.uk/Isereviewofbooks/2012/11/17/book-review-politics-in-deeply-divided-societies-by-adrian-guelke/.

25 Alexandra Amling, Marie O’Reilly, Kelsey Coolidge, Brittany Persinger, and Emmicki Roos, “From Global Promise to National Action: Advancing Women, Peace, and Security in the Democratic Republic of Congo, the Philippines, Serbia, and Sierra Leone" (Denver, Colorado: One Earth Future Foundation and Inclusive Security, October 19, 2016), 34-35, http://oefresearch. org/publications/global-promise-national-action-advancing-women-peace-and-security-democratic-republic.

26 Hafner-Burton and Tsutsui, "Justice Lost! The Failure of International Human Rights Law to Matter Where Needed Most."

27 Keck and Sikkink, Activists Beyond Borders.

28 University Research Council, Ateneo de Davao, Davao City, Philippines, interview by Kelsey Coolidge, Brittany Persinger, and Cecilia Dalupan, September 7, 2015.

29 "Magna Carta of Women (RA 9710)" (Office of the President, Philippine Commission on Women, April 2010), http://pcw.gov. ph/law/republic-act-9710.

30 Alexandra Amling et al., "From Global Promise to National Action: Advancing Women, Peace, and Security in the Democratic Republic of Congo, the Philippines, Serbia, and Sierra Leone" (Denver, Colorado: One Earth Future Foundation and Inclusive Security, October 19, 2016), http://oefresearch.org/publications/global-promise-national-action-advancing-women-peace-and-security-democratic-republic.

31 "Civil Society Briefs: Philippines," Asian Development Bank, February 2013.

32 Kate McGeown, "People Power at 25: Long Road to Philippine Democracy," BBC News, February 25, 2011, sec. Asia-Pacific, http://www.bbc.com/news/world-asia-pacific-12567320.

33 Caucus of Development NGO Networks, "Civil Society Index: A Philippine Assessment Report," Assessment Report (Quezon City, Philippines, August 2011), ix.

34 Women and Gender Institute, Miriam College, Manila, Philippines, interview by Kelsey Coolidge, Brittany Persinger, and Cecilia Dalupan, September 1, 2015; Philippine Commission on Women, Manila, Philippines, interview by Kelsey Coolidge, Brittany Persinger, and Cecilia Dalupan, September 3, 2015; Philippine Council of Islam and Democracy, Manila, Philippines, interview by Kelsey Coolidge, Brittany Persinger, and Cecilia Dalupan, September 4, 2015; Mindanao's Peoples Caucus, Davao City, Philippines, interview by Kelsey Coolidge, Brittany Persinger, and Cecilia Dalupan, September 7, 2015; Philippine Women's College of Davao, Davao City, Philippines, interview by Kelsey Coolidge, Brittany Persinger, and Cecilia Dalupan, September 7, 2015;

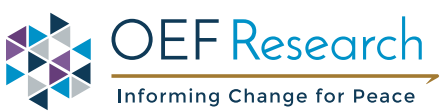


Al Qalam Institute for Islamic Identities and Dialogue in Southeast Asia, Ateneo de Davao University, Davao City, Philippines, interview by Kelsey Coolidge, Brittany Persinger, and Cecilia Dalupan, September 9, 2015.

35 International Crisis Group, “The Philippines: Renewing Prospects for Peace in Mindanao," Asia Report, July 6, 2016, 2, https:// d2071andvip0wj.cloudfront.net/281-the-philippines-renewing-prospects-for-peace-in-mindanao.pdf.

36 While the interview data collected for the NAP report focused on the conflict between the Moro Islamic Liberation Front (MILF) and the national government, it is otherwise important to note the activity of other armed groups in the Philippines at the time which motivated martial rule and were targets of government-sponsored violence. The National Democratic Front, a leftist resistance organization, also opposed the Marcos regime, engaged in direct hostilities with national government forces, and is currently in stalled peace negotiations with the national government. Additionally, though the Moro National Liberation Front (MNLF) initiated open rebellion against the national government, it is no longer considered the representative of the Moro secessionist movement. A major split in the aftermath of failed peace talks led to the creation of the MILF, which now represents the Moro community in negotiations with the national government. Several other splinter groups have subsequently broken off from the MNLF and MILF, including Abu Sayyaf. This group has been actively involved in terrorism and piracy in the southern Philippines.

37 International Crisis Group, “The Philippines: Renewing Prospects for Peace in Mindanao."

38 Ibid., 2-4.

39 Mindanao's Peoples Caucus, interview by Coolidge, Persinger, and Dalupan; Al Qalam Institute for Islamic Identities and Dialogue in Southeast Asia, interview by Coolidge, Persinger, and Dalupan; Philippine Women's College of Davao, interview by Coolidge, Persinger, and Dalupan.

40 Mindanao's Peoples Caucus, interview by Coolidge, Persinger, and Dalupan.

41 Ibid.

42 Patrick Symmes, "President Duterte's List," New York Times, January 10, 2017, https://www.nytimes.com/2017/01/10/magazine/president-dutertes-list.html.

43 Ibid.

44 Phil Zabriskie, "The Punisher," Time, July 19, 2002, http://content.time.com/time/magazine/article/0,9171,265480,00.html.

45 Ibid.

46 Ibid.

47 "Republic Act 7192," Philippine Commission on Women, 71, accessed August 30, 2016, http://www.pcw.gov.ph/law/republic-act-7192.

48 “Anti-Rape Law of 1997," Wikipilipinas: The Hip 'N Free Philippine Encyclopedia, accessed August 30, 2016, http://en.wikipilipinas.org/index.php/Anti-Rape_Law_of_1997.

49 "Anti-Violence Against Women and Their Children Act (RA 9262)," Captain Barangay to the Rescue!, February 14, 2009, https://captainbarangay.wordpress.com/laws/anti-violence-against-women-and-their-children-act-ra-9262/.

50 Philippine Commission on Women, interview by Coolidge, Persinger, and Dalupan; Women and Gender Institute, interview by Coolidge, Persinger, and Dalupan; University Research Council, interview by Coolidge, Persinger, and Dalupan.

51 Integrated Gender and Development Division of the Office of the Mayor, Davao City, Philippines, interview by Kelsey Coolidge, Brittany Persinger, and Cecilia Dalupan, September 8, 2015.

52 University Research Council, Ateneo de Davao, interview by Coolidge, Persinger, and Dalupan.

53 Integrated Gender and Development Division of the Office of the Mayor, interview by Coolidge, Persinger, and Dalupan; University Research Council, Ateneo de Davao, interview by Coolidge, Persinger, and Dalupan.

54 Mindanao's Peoples Caucus, interview by Coolidge, Persinger, and Dalupan.

55 University Research Council, Ateneo de Davao, interview by Coolidge, Persinger, and Dalupan.

56 Integrated Gender and Development Division of Office of the Mayor, interview by Coolidge, Persinger, and Dalupan.

57 “City Ordinance No. 5004 and Executive Order No. 24," Office of the Mayor, Davao City, October 1997, 3-4.

58 Integrated Gender and Development Division of the Office of the Mayor, interview by Coolidge, Persinger, and Dalupan.

59 Official Development Assistance includes all "funds received from foreign governments and multilateral agencies," "City Ordinance No. 5004 and Executive Order No. 24."

60 Ibid., 3.

61 Sangguniang Panlungsods are city government legislatures in the Philippines.

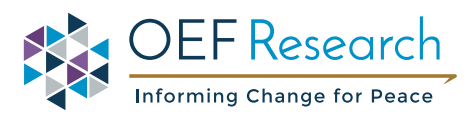


62 "City Ordinance No. 5004 and Executive Order No. 24," 13.

63 Barangay Councils are the lowest government bodies in the Philippines, formerly known as Rural or Barrio Councils.

64 University Research Council, Ateneo de Davao, interview by Coolidge, Persinger, and Dalupan.

65 "GAD Local Learning Hub-Davao City," Philippine Commission on Women, September 7, 2015, http://www.pcw.gov.ph/casestudy/gad-local-learning-hub-davao-city.

66 Integrated Gender and Development Division of the Office of the Mayor, interview by Coolidge, Persinger and Dalupan.

67 Ibid.

68 "GAD Local Learning Hub-Davao City," Philippine Commission on Women.

69 Integrated Gender and Development Division of the Office of the Mayor, interview by Coolidge, Persinger and Dalupan.

70 "GAD Local Learning Hub-Davao City," Philippine Commission on Women.

71 "The Galing Pook Awards," Galing Pook Foundation, accessed September 13, 2016, http://www.galingpook.org/awards.

72 Philippine Information Agency, "IGDD Earns Galing Pook 2004 Citation," PIA Press Release, October 28, 2004, http://archives. pia.gov.ph/?m=12\&sec=reader \&rp=1\&fi=p041028.htm\&no=10\&date=10/28/2004

73 James Raymond Vreeland, "Political Institutions and Human Rights: Why Dictatorships Enter into the United Nations Convention Against Torture," International Organization 62, no. 1 (Winter 2008): 65-101.

74 Min Zhou, "Signaling Commitments, Making Concessions: Democratization and State Ratification of International Human Rights Treaties, 1966-2006," Rationality and Society 26, no. 4 (November 1, 2014): 475-508, doi:10.1177/1043463114546313.

75 Zabriskie, "The Punisher."

76 University Research Council, Ateneo de Davao, interview by Coolidge, Persinger, and Dalupan.

77 Xiane Arcangel, "Amnesty International Calls Out Duterte's Drug War," CNN Philippines, February 22, 2017, http://cnnphilippines.com/news/2017/02/22/amnesty-international-calls-out-dutertes-drug-war.html.

78 Bong Garcia, "4 Killed, 15 Wounded in Davao Roadside Bombing, Firefight," SunStar Philippines, February 17, 2017, http:/ www.sunstar.com.ph/zamboanga/local-news/2017/02/17/4-killed-15-wounded-davao-roadside-bombing-firefight-526327.

79 "The Adoption of the NAP on UNSCR 1325 in Palestine: A Milestone for Palestinian Women and Girls in Working Towards Peace," UN Women, August 24, 2016, http://palestine.unwomen.org/en/news-and-events/stories/2016/08/palestinenap. 


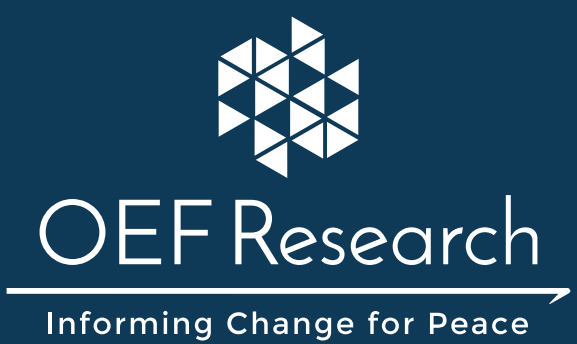

OEF Research is a program of

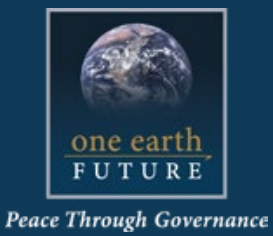

www. oneearthfuture.org 